\title{
Oncogenic hypophosphataemia and ectopic corticotrophin secretion due to oat cell carcinoma of the trachea
}

\author{
C van Heyningen, A R T Green, I A MacFarlane, C T Burrow
}

\begin{abstract}
A case of oat cell carcinoma causing Cushing's syndrome and oncogenic hypophosphataemic osteomalacia is reported. The association of the two disorders in one patient is believed to be unique and this is the second reported case of oncogenic osteomalacia caused by oat cell carcinoma.
\end{abstract}

$(\mathcal{F}$ Clin Pathol 1994;47:80-82)

Oncogenic hypophosphataemia is a rare disorder of which at least 70 cases have been reported. ${ }^{1}$ It is associated with hyperphosphaturia and abnormalities of vitamin $D$ metabolism that lead to osteomalacia. ${ }^{2}$ The metabolic disorder is caused by a tumour which, in most cases, is benign and single, but may be multiple, and in 10 cases was malignant. ${ }^{1}$ Only one case has been reported of this disorder resulting from a malignant lung tumour-an oat cell carcinoma that concurrently produced antidiuretic hormone. ${ }^{3}$ We report a case of hypophosphataemic osteomalacia occurring in a patient with a corticotrophin (ACTH) secreting oat cell carcinoma.

\section{Case report}

A 58 year old woman presented in October 1990 with a two month history of dysphagia, epigastric pain, and weight loss (1 stone). She had a history of asthma and smoked 10 cigarettes daily. Serum biochemistry comprised sodium $143 \mathrm{mmol} / \mathrm{l}$, potassium $4.6 \mathrm{mmol} / \mathrm{l}$,

Accepted for publication

29 July 1993
Biochemical results during second admission

\begin{tabular}{|c|c|c|}
\hline & & Reference ranges \\
\hline \multicolumn{3}{|l|}{ Serum: } \\
\hline Cortisol & $\begin{array}{l}1252 \mathrm{nmol} / 1 \text { at } 9 \mathrm{am} \\
1166 \mathrm{nmol} / 1 \text { at midnight } \\
1661 \mathrm{nmol} / 1 \text { after } 2 \mathrm{mg} \\
\text { dexamethasone test }\end{array}$ & $\begin{array}{l}130-690 \mathrm{nmol} / 1 \\
<170 \mathrm{nmol} / 1\end{array}$ \\
\hline ACTH & $\begin{array}{l}\text { dexamethasone test } \\
670 \mathrm{pg} / \mathrm{ml} \text { at } 9 \mathrm{am}\end{array}$ & $\begin{array}{l}<160 \mathrm{nmol} / 1 \\
10-80 \mathrm{pg} / \mathrm{ml}\end{array}$ \\
\hline ACTH precursors & $2275 \mathrm{pmol} / 1$ & $10-39 \mathrm{pmol} / 1$ \\
\hline Parathyroid hormone & $13.4 \mathrm{pmol} / 1$ & $1.1-6.9 \mathrm{pmol} / 1$ \\
\hline $\begin{array}{l}\text { Calcium } \\
\text { Albumin }\end{array}$ & $2.05 \mathrm{mmol} / 1$ & $2 \cdot 18-2 \cdot 62 \mathrm{mmol} / 1$ \\
\hline Phosphate & $0.36 \mathrm{mmol} / 1$ & $0.7-1.6 \mathrm{mmol} / 1$ \\
\hline PTH related peptide & $2.0 \mathrm{pmol} / 1$ & $<2.6 \mathrm{pmol} / 1$ \\
\hline $25 \mathrm{OH}$ vitamin D2 & $<2 \mathrm{ng} / \mathrm{ml}$ & $<10 \mathrm{ng} / \mathrm{ml}$ \\
\hline $\begin{array}{l}25 \mathrm{OH} \text { vitamin D3 } \\
1,25(\mathrm{OH}) \text { vitamin } \mathrm{D} 3\end{array}$ & $\begin{array}{l}8 \mathrm{ng} / \mathrm{ml} \\
24.8 \mathrm{pg} / \mathrm{ml}\end{array}$ & $5-25 \mathrm{ng} / \mathrm{ml}$ \\
\hline \multicolumn{3}{|l|}{ Urine: } \\
\hline Tubular reabsorption of phosphate & $54 \%$ & $80-90 \%$ \\
\hline Phosphate clearance & $42 \mathrm{ml} / \mathrm{min}$ & $5-15 \mathrm{ml} / \mathrm{min}$ \\
\hline $\begin{array}{l}\text { Phosphate excretion index } \\
\text { Cortisol }\end{array}$ & 0.465 & +0.08 to -0.08 \\
\hline & $-000011001 / 2411$ & $30-100 \mathrm{MINO} / 24 \mathrm{n}$ \\
\hline
\end{tabular}

urea $4.4 \mathrm{mmol} / \mathrm{l}$, glucose $5 \cdot 1 \mathrm{mmol} / \mathrm{l}$, calcium $2.40 \mathrm{mmol} / \mathrm{l}$, phosphate $1.11 \mathrm{mmo} / \mathrm{l}$, alkaline phosphatase (ALP) $116 \mathrm{U} / 1$ (reference range 30-130 U/1), and albumin $42 \mathrm{~g} / 1$. On endoscopy a broad based pedunculated lesion was found in the oesophagus at $35 \mathrm{~cm}$ distal to the incisors, with no abnormality seen in the stomach or duodenum. A biopsy specimen was taken which showed the presence of an oat cell carcinoma. No abnormality was seen on chest radiology nor on bronchoscopy. An oesophagogastrectomy was performed in December 1990.

A year later she complained of ankle swelling, dysphagia, and widespread bone and joint pains. She had noticeable hypophosphataemia (serum phosphate 0.32 $\mathrm{mmol} / \mathrm{l}$ ) with sodium at $143 \mathrm{mmol} / \mathrm{l}$, potassium $4.0 \mathrm{mmol} / \mathrm{l}$, urea $5.5 \mathrm{mmol} / \mathrm{l}$, glucose $7.3 \mathrm{mmol} / \mathrm{l}$, calcium $2.24 \mathrm{mmol} / \mathrm{l}$, ALP 195 $\mathrm{U} / 1$ and albumin $39 \mathrm{~g} / 1$.

On admission to hospital one month later she had a puffy face, increased pigmentation, and bilateral lower leg pitting oedema. Hypophosphataemia persisted (serum phosphate $0.25 \mathrm{mmol} / \mathrm{l}$ ) and other serum biochemistry was now sodium $141 \mathrm{mmol} / \mathrm{l}$, potassium $2.9 \mathrm{mmol} / \mathrm{l}$, glucose $13.7 \mathrm{mmol} / \mathrm{l}$, calcium $2.11 \mathrm{mmol} / 1$, albumin $38 \mathrm{~g} / \mathrm{l}$. The urine was negative for ketones. She was treated with oral potassium salts, frusemide, and subcutaneous insulin. Further biochemical results are shown in the table. The raised serum and urine cortisol values, the lack of suppression with overnight dexamethasone, and the substantially raised adrenocorticotrophic hormone (ACTH) and ACTH precursor values were consistent with a diagnosis of Cushing's syndrome due to ectopic ACTH secretion. The reduced tubular reabsorption of phosphate and increased phosphate clearance and urinary excretion indicated renal tubular phosphate loss.

Metyrapone was given to control corticosteroid production but unfortunately she died suddenly four days later. Two days before death the serum phosphate was still low (phosphate $0.35 \mathrm{mmol} / \mathrm{l}$ ).

\section{Pathology}

The endoscopic biopsy specimen taken from the pedunculated lesion in the oesophagus showed oat cell carcinoma. (fig 1). The subsequent resection specimen showed no intraluminal or epithelial lesion, only metastatic oat cell carcinoma in one of the oesophageal lymph nodes. At post mortem examination a 


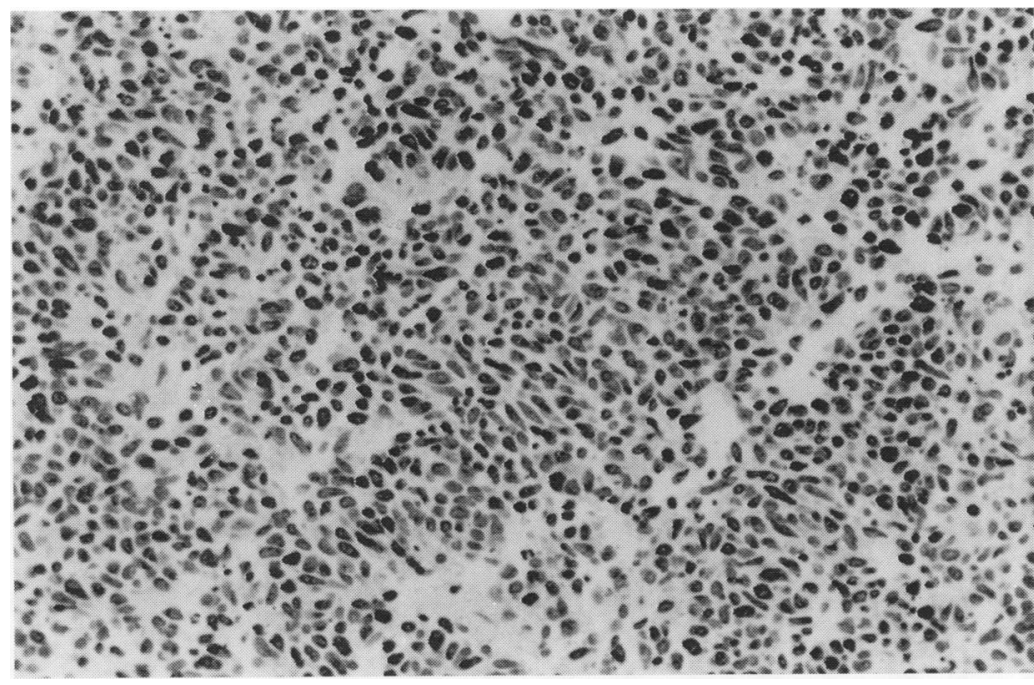

Figure 1 Biopsy specimen of oesophagus. Small cell carcinoma, oat cell type.

$5 \mathrm{~cm}$ in diameter tumour was found situated between the remaining oesophagus and trachea, bulging into the oesophageal lumen. The tumour surrounded the full circumference of the lower trachea, and there was slight irregularity of the tracheal mucosa. The oesophageal mucosa and bronchial mucosa appeared normal.

Metastatic tumour was present in bronchial and paratracheal lymph nodes, and on the visceral pleura of both lungs. Metastases were also seen in the liver, pancreas, and adrenal glands, and in the vertebrae. The kidneys and parathyroid glands showed no evidence of disease.

Histological examination of the trachea showed that tumour was present in the mucosa, infiltrating deeply into adjacent tissue. The tumour was composed of cells with oval or round nuclei with indistinct cytoplasm. The cells were arranged in solid sheets or trabeculae. Mitoses were common and there were areas of necrosis. The features

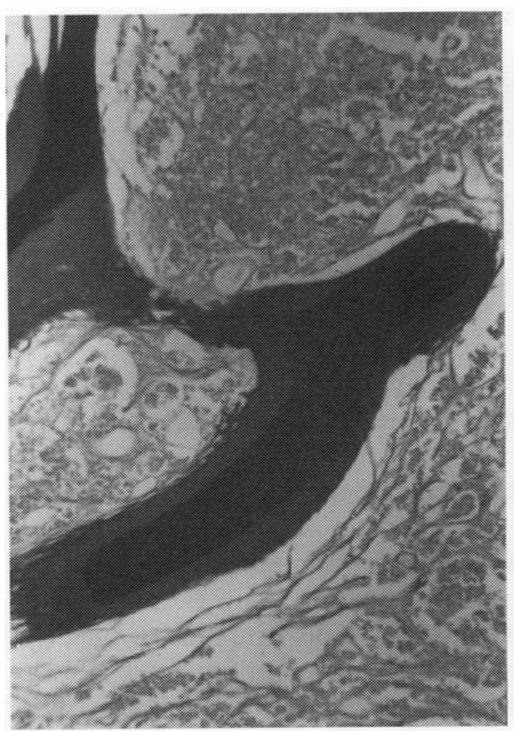

(A)

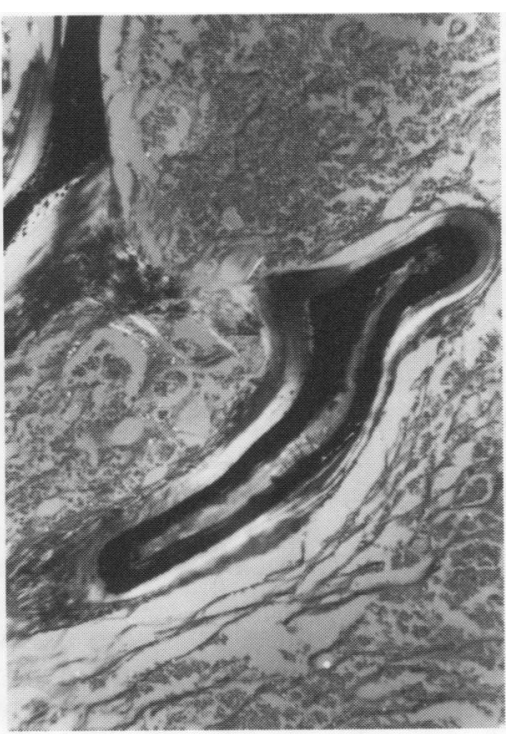

(B)
Figure 2 Widened osteoid seams in vertebral bone: $(A)$ by non-polarised microscopy; (B) by polarisation microscopy. were consistent with those of primary small cell carcinoma, oat cell type, of the trachea. Bronchial mucosa sampled looked normal with no evidence of tumour. Electron micrographs of tumour tissue showed intracytoplasmic dense core secretory granules, as seen in neuroendocrine cells, ${ }^{4}$ confirming the diagnosis of oat cell carcinoma. The oesophageal mucosa was intact, although attenuated in places. The muscle wall and adjacent tissues were infiltrated by oat cell carcinoma. Vertebral bone showed widened osteoid seams around the bony trabeculae, consistent with osteomalacia (fig 2), and in other areas metastatic tumour was present.

Parathyroid hormone related peptide messenger RNA (PTHrP m-RNA) was not shown in tumour tissue by use of the reverse transcriptase polymerase chain reaction. $\beta$ actin signal was seen in this tissue.

\section{Discussion}

The complex biochemical abnormalities and histopathological findings were consistent with a probable diagnosis of oncogenic hypophosphataemic osteomalacia and ectopic Cushing's syndrome resulting from an oat cell carcinoma. As far as we are aware this is the first report of these two paraneoplastic syndromes occurring together and the second report of oncogenic osteomalacia attributable to oat cell carcinoma.

Oncogenic hypophosphataemia is thought to be caused by the secretion from the tumour of a hormonal factor that inhibits 25hydroxyvitamin D 1-hydroxylase activity and phosphate reabsorption in the renal tubules. ${ }^{1}$ Low concentrations of 1,25-dihydroxyvitamin D have been found ${ }^{5}$ and, in one study, an extract from a fibroangioma produced a phosphaturic response in dogs. ${ }^{6}$ In our patient no abnormality of vitamin $\mathrm{D}$ metabolism was shown.

Generally plasma parathyroid hormone values are normal in oncogenic osteomalacia. ${ }^{5}$ The increased intact PTH concentration in our case may have contributed to renal phosphate wasting. The increased intact parathyroid hormone production may have been a response of the normal parathyroid glands to reduced serum calcium concentration (resulting from calcium suppression by hypercortisolemia), may have resulted from ectopic parathyroid hormone production by the tumour, or may have been secondary to the development of osteomalacia. The normal parathyroid hormone related peptide concentration and the lack of PTHrP m-RNA in tumour tissue suggest that PTHrP was not involved in the production of phosphaturia. Such a factor which, like parathyroid hormone, stimulates renal adenylate cyclase, has been described in extracts of tumours from three patients with oncogenic osteomalacia. ${ }^{7}$ A recent commentary on tumour induced osteomalacia speculates that alternative PTHrP gene products may be secreted by tumours to stimulate phosphate excretion. ${ }^{8}$ These alternative peptides are yet to be identified. 
We are grateful to Dr W Fraser for vitamin D and PTHrP measurements and to Dr A White for ACTH and ACTH precursor measurements.

1 Paterson CR, Naismith KI, Young JA. Severe unexplained hypophosphatemia. Clin Chem 1992;38:104-7.

2 Drezner MK, Fenglos MN. Osteomalacia due to 125 dihydroxy-cholecalciferol deficiency: association with giant cell tumour of bone. $₹$ Clin Invest 1977;60: 1046-53.

3 Taylor HC, Fallon MD, Velasco ME. Oncogenic osteomalacia and inappropriate antidiuretic hormone secretion due to oat-cell carcinoma. Ann Intern Med 1984;101:786-8.
4 Ratcliffe JG. Endocrine effects of tumours. In: McGee JO'D, Isaacson, PG, Wright NA, eds. Oxford textbook of pathology. Vol 1. Oxford: OUP, 1992:694-703.

5 Ryan EA, Reiss E. Oncogenous osteomalacia: review of world literature of 42 cases and report of two new cases. Am ₹ Med 1984;77:501-12.

6 Aschinber LC, Solomon LM, Zeis PM, et al. Vitamin resistant rickets associated with epidermal nevus syndrome. $¥$ Pediatr 1977;91:56.

7 Seshadri MS, Cornish CJ, Mason RS, et al. Parathyroid hormone-like bioactivity in tumours from patients with hormone-like bioactivity in tumours from patients

8 Hewison M, Karmali R O'Riordan ILH. Tumou induced M, Karmali R, Oriordan JLH. Tumo

\title{
Gram negative septicaemia diagnosed on peripheral blood smear appearances
}

\author{
A Fife, D Hill, C Barton, P Burden
}

\begin{abstract}
Buffy coat smears from febrile patients may contain visible bacteria and therefore detect bacteraemia before conventional blood cultures become positive. However, it is unusual to see microorganisms in an otherwise untreated peripheral blood smear. The case of a febrile neutropenic patient is reported. A Wright's stained peripheral blood smear contained bacterial elements, thus making earlier diagnosis of septicaemia and identification of the causative bacterium possible.
\end{abstract}

(F Clin Pathol 1994;47:82-84)

\section{Case report}

A 59 year old woman was undergoing chemotherapy with ifosfamide and epirubicin for recurrent adenocarcinoma of the ovary following a disease free period of five years. Response to carboplatin had been limited and the patient had undergone surgical debulking of the residual tumour some five months earlier. A Hickman line had been inserted and the ifosfamide/epirubicin regimen started six weeks before the episode described here. The patient had already had a septicaemic episode (not associated with neutropenia) one month earlier. Two sets of blood cultures (cultured by the Sentinel method, Difco, UK) taken at this time were positive for Staphylococcus aureus and one set had also yielded Klebsiella oxytoca. She responded well to flucloxacillin and gentamicin.

She had undergone her third course of ifosfamide and epirubicin 10 days earlier and this had been complicated by the transient development of signs of ifosfamide toxicity which completely resolved.

A week after discharge she was admitted with a 24 hour history of rigors, vomiting, and epistaxis. Her general practitioner had given her oral cephradine the day before admission.

Examination showed that the patient was pale and obviously unwell. She was initially apyrexial. Despite the reported epistaxis there was no other evidence of abnormal bleeding. Her pulse rate was 84 per minute and her blood pressure 120/70 mm $\mathrm{Hg}$. Apart from mild ankle oedema there were no other cardiovascular signs and the respiratory system was also normal. The abdomen was soft and non-tender with no hepatosplenomegaly. She did not appear to be confused and there were no focal neurological signs.

A set of blood cultures was taken from the Hickman line, along with samples for full blood count, urea, and electrolytes and liver function tests. A mid-stream urine specimen was also obtained and the patient was given cefuroxime intravenously. Results of the initial investigations showed a haemoglobin concentration of $71 \mathrm{~g} / 1$ and a profound leucopenia of $0.2 \times 10^{9} / 1$. Her platelet count was also low at $31 \times 10^{9} / 1$. She was hypokalaemic with a potassium concentration of $2 \cdot 1 \mathrm{mmol} / 1$ and had evidence of mild renal impairment which had not been present before.

Soon after admission the patient deteriorated and showed overt signs of sepsis. Her temperature rose to $39^{\circ} \mathrm{C}$ and she developed a tachycardia of 100 per minute which was accompanied by a drop in blood pressure to $100 / 60 \mathrm{~mm} \mathrm{Hg}$. A urinary catheter was inserted to monitor output and resuscitation with intravenous fluids begun. Her antibiotic treatment was changed to piperacillin $4 \mathrm{~g}$ four times daily and gentamicin $80 \mathrm{mg}$ three times daily in keeping with the regimen for febrile neutropenia in use in this hospital. She was given blood and platelet support.
Correspondence to: Dr A J Fife 